\title{
Être and paraître: The games of truth in the book of Susanna
}

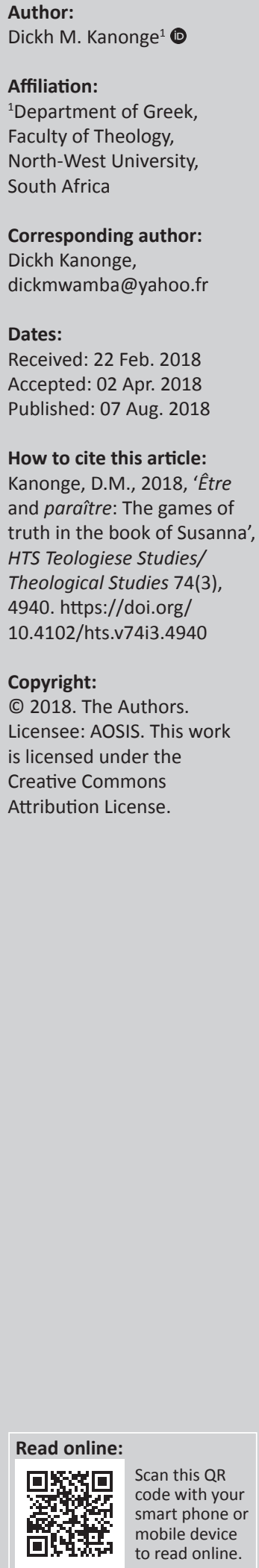

Recent literary methods have opened new possibilities in reading and understanding the logic of narratives. The Greimassian approach offers such a possibility. Though Greimas' approach is by now accepted as part of the canon of narratology, some of its components have not yet received due attention. This is the case with his 'veridictory square', a diagram that applies especially to texts where oppositions such as truth-falsehood, hero-villain and subject-anti-subject are prominent themes. This article aims to demonstrate that these kinds of narratives, such as Susanna, do not concern themselves with objective truth but persuasion about truth, that is, veridiction. Truth telling in those stories corresponds to manipulation, exercising a particular cognitive doing or causing to appear as true. In other words, such a manipulation of truth aims at causing people to believe. Using Greimas' veridictory square built on opposing modalities of being (être) and seeming (paraitre), the contrast between reality and appearance, this article provides insight into the games of truth in Susanna and thus offers a new inspiring way of reading these kinds of stories.

\section{Introduction}

This article attempts to investigate the games of truth in the book of Susanna ${ }^{1}$ using Greimas' veridictory square. Susanna is an addition to Daniel that is not included in the Jewish and Protestant canons of sacred scriptures (Tate 1968:340; cf. Sundberg 1966). Even in the Catholic canon where it does feature, Susanna and other apocryphal books appear as minor scriptures. In fact, according to Mills and Wilson (2002: xvi), 'Roman Catholics call these books "Deuterocanonical" - secondarily canonical or added latter to the canon'. Surprisingly, however, Susanna is one of the most interpreted and most reproduced stories of the ancient world, from late antiquity until postmodern times. The development of scholarship literature on Susanna follows the same scientific trajectory as all other LXX Apocrypha and can be classified into three main groups as follows:

- Apocrypha books, including Susanna, were first studied by Böckler (1891) in his Apocryphen des Alten Testaments; Kautzsch (2009) in Apocryphen und Pseudepigraphen des Alten Testaments; Charles (1913; cf. Kay 1913 on Susanna) in Apocrypha and Pseudepigrapha of the Old Testament and Ziegler (1999) in Susanna, Daniel, Bel et Draco. These works prove their importance in stabilising the texts and providing insights for translation.

- The second wave of studies is associated with Oesterley (1935) in An Introduction to the Books of the Apocrypha; Pfeiffer (1949) in History of New Testament Times, with an Introduction to the Apocrypha; Metzger (1957) in An Introduction to the Apocrypha; Goodspeed (1971) in The Story of the Apocrypha; Dancy (1972) in The Shorter Books of the Apocrypha: Tobit, Judith, Rest of Esther, Baruch, Letter of Jeremiah and Additions to Daniel and Prayer of Manasseh; Moore (1977) in Daniel, Esther and Jeremiah: The Additions; Kottsieper (1998) in Das Buch Baruch Der Brief des Jeremia Zu Esther und Daniel; Wills (2004) in Ancient Jewish Novels: An Anthology; DiTommaso (2005) in The Book of Daniel and the Apocryphal Daniel Literature. These publications are more or less based on the historical critical approach to texts (cf. 2.1). One of the main gains of these studies was to expose the literary genre of the different books. They also uncovered various problems in the texts that still needed to be addressed (Jordaan \& Kanonge 2006).

- The third group includes numerous works such as Casey (1976) in The Susanna Theme in German Literature: Variations of the Biblical Drama; Dunn (1982) in Discrimination in the Comic Spirit in the Story of Susanna; Steussy (1993) in Gardens in Babylon: Narrative and Faith in the Greek Legends of Daniel; Brenner (1995) in A Feminist Companion to Esther, Judith and Susanna; Harrington (1999) in Invitation to the Apocrypha; Craven (1998) in The Greek Book of Daniel

1.The text of Susanna analysed here is essentially Theodotion's version, which has a most elaborate narrative, focusing more on Susanna than the Old Greek does. In this article, Susanna (italicised) refers to the story entitled Susanna, while Susanna (non-italicised) refers to its female protagonist. The apocryphal story of Susanna is an addition found at the end of the Greek book of Daniel in the LXX (cf. Chapter 13). The LXX Greek text is quoted from Rahlfs' (1996) edition of the LXX. 
(cf. also Craven 1992 \& 2001); Ilan (2001) in Integrating Women into Second Temple History; Bohn (2001) in Rape and the Gendered Gaze: Susanna and the Elders in Early Modern Bologna; DeSilva (2002) in Introducing the Apocrypha; Clanton (2006) in The Good, the Bold and the Beautiful; Cornelius (2008) in "The Woman in "Susanna": An Understanding of the Rhetoric of "Susanna"'; Jordaan (2008) in 'Reading Susanna as Therapeutic Narrative'; Steyn (2008) in "“Beautiful but Tough": A comparison of LXX Esther, Judith and Susanna'; and Tkacz (2008) in 'Susanna and the Pre-Christian Book of Daniel: Structure and Meaning' (cf. 1998), to name but a few. With a growing interest in the Second Temple period, these scholars take a major step forward in the treatment of the Apocrypha. While taking into account the contribution of other scholars, they deal with texts in terms of the ideology behind them, such as gender roles, power struggle, body and space.

Most of the aforementioned contributions about Susanna consist of commentaries, essays and articles, monographs and reviews. Commentaries on Susanna are historical critical studies of the narrative that certainly shed light on historical, linguistic and textual dimensions of the narrative, yet leave behind the plot and characterisation. Because plot and characterisation are not their primary concern, they are inadequate for the study of Susanna and the elders as characters.

Essays and articles constitute the most abundant contribution to Susanna's scholarship, but despite their abundance none of them has yet attempted to study the book using the veridictory square, which this article will do by testing the plausibility of Greimas' diagram in the context of Susanna. The main problem to address may be formulated as follows: How does the semiotic square of veridiction, that is, the contrast between être and paraitre on the one hand, and their opposite values, non-être and non-paraitre on the other hand, shape the flow of knowledge in the book of Susanna? In other words, how do the four modal categories of 'truth', 'falsehood', 'secret' and 'lie' stemming from these contrasting modalities of being and seeming and their opposite values (non-being and non-seeming) prove their effectiveness in the reading of Susanna?

\section{Method}

As stated, this study adopts the Greimassian approach to narrative, which consists of three levels of analysis: the figurative, the narrative and the thematic. The figurative level of analysis (Greimas \& Rastier 1968:48) focuses on figures and how they are constructed by the author (EveraertDesmedt 2007:30). The narrative level of analysis examines the organisation of the text as discourse. This step of analysis helps reveal different functions of actors (called at this stage 'actants') and traces the course of the subject (main character) across the narrative. At the thematic level, the researcher will strive to uncover the fundamental values that caused the text. The core of these values is generally expressed implicitly by a narrative, and the paradigmatic and syntagmatic use of the semiotic square allows us to discover the core of values in a narrative. This mechanism of analysis relies on opposing values in the narrative and their contradictory values. The veridictory square, which is the subject of this article, is a semiotic square built on the modalities of être and paraitre [being and seeming] and their contradictory values, non-être and non-paraître [non-being and non-seeming], as stated.

The philosophy behind the square is the contention that storytellers' concern in general, and Susanna in particular, is persuasion about truth and falsehood, that is, veridiction. The construction of truth corresponds to exercising a particular cognitive doing or causing to appear as true. The purpose of such manipulation of truth is 'causing to believe'. Our experience of the real world is limited by what happens to be our point of view and, as such, we should not assume that such a point of view gives us access to the way things really are (Harries 2001:51); thus the reality of an utterance (technical term for 'statement' in the Greimassian semiotics) might be different from the reality of the natural world (Speelman 1995:27). This is where Greimas' veridictory square reveals its importance.

The Greimassian approach to narratives is nowadays accepted as part of the canon of narratology, and it is therefore beyond the scope of this study to scrutinise it. In fact, much has already been said about Greimas' semiotics, underlying their strengths and weaknesses. Greimas' critics include Budniakiewicz (1992), Everaert-Desmedt (2007), Longman (1996), Pottier (2006), Ricoeur (1989a; 1989b) and Schleir (1987). These scholars provide evaluations of Greimas' thought in terms of plausibility. The aim here is only to test the mechanism on a biblical narrative, namely Susanna.

The semiotic square of veridiction, also known as the 'veridictory square', is now described.

\section{The semiotic square of veridiction}

The semiotic square of veridiction serves the purpose of tracking the process of truth telling in a story, in connection with the flow of knowledge, or lack thereof, within a text. In fact, it is the contention of Greimas and his followers that as the story unfolds, truth telling becomes a game, a kind of hide-and-seek. Therefore, some actors in the narrative know more than the others; some are deceived and others are misunderstood. Readers may also be either enlightened or kept in the dark because vital information can be kept from them until the very end (Martin 2006:208). In other words, reality is constructed on the changing modes of being (être) and seeming (paraître), on certainty and appearance (cf. Courtés 1991:11-119, 1995:81-84; Hénault 1983:61-62; Speelman 1995:26). Built on être and paraitre [being and seeming], the veridictory square has the following configuration.

In Figure 1, être and paraître, non-être and non-paraître, être and non-paraître and finally paraître and non-être bring about four 


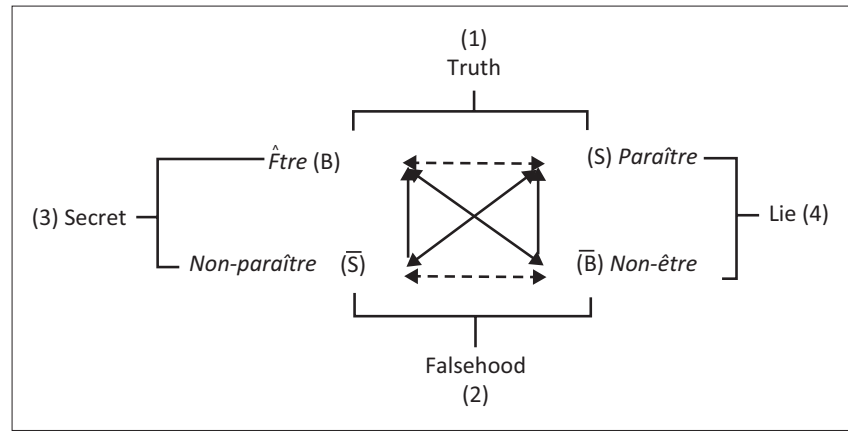

Source: Courtés, J., 1991, Analyse sémiotique du discours: de l'énoncé à l'énonciation, Hachette, Paris; Courtés, J. 1995, Du lisible au visible, De Boeck Université, Bruxelles; Hénault, A., 1983, Narratologie Sémiotique Générale. Les enjeux de la Sémiotique II, Presses universitaires de France, Paris

FIGURE 1: Illustration of a veridictory square in a narrative.

modal categories of 'truth', 'falsehood', 'secret' ('mystery') and 'lie' ('illusion'). The two opposing modal categories, such as truth versus falsehood on one side and secret versus lie on the other side, are called 'meta-terms'. The combination of être and non-paraître on one side, and paraitre and non-être on the other side, constitutes a deixis. A 'deixis' refers to the link between one of the contrary terms with the contradictory of the other term (Martin \& Ringham 2000:48). In general, 'secret' (être and non-paraître) is situated on the positive deixis, while 'lie' (paraitre and non-être) is on the negative. The four modal categories are described next.

\section{The four modal categories}

As said above, 'truth' and 'falsehood', 'secrets' and 'lies' constitute the four modal categories of veridiction. The interpretation of the diagram in Figure 1 may seem sometimes complicated and puzzling, and drawing conclusions using this chart depends on each narrative. However, in general, it can provide the reader of a story with the following insights.

\section{Truth}

'Truth' is a modal category resulting from the combination of être and paraitre. In other words, '[i]f something seems and is, then it is true' (Speelman 1995:25). Truth corresponds to the way things really are. In most stories, truth is revealed only at the end of the story. The moment of truth is generally associated with the revelation of the hero based on undeniable evidence. It corresponds to what is known as positive sanction for the hero (Everaert-Desmedt 2007:61).

\section{Falsehood}

'Falsehood' is the combination of non-être and non-paraître: if something seems not and is not, then it is false. This corresponds to the exposure of imposture in narratives. In most narratives, falsehood is unmasked only at the end of the story; this corresponds to a negative sanction for the anti-subject.

\section{Secret}

On the semiotic square of veridiction, the term 'secret' subsumes the complementary terms of 'being' and 'nonseeming', which are located on the positive deixis (Martin \& Ringham 2000:113). It is also a synonym for 'concealment', 'mystery' or 'camouflage'. It designates what is but does not appear. In other words, if something does not seem true while being true, then there is a secret. This corresponds to mystification.

\section{Lie}

On the semiotic square of veridiction, the term 'lie' (illusion) subsumes the complementary terms of 'seeming' and 'nonbeing', which are found on the negative deixis (Martin \& Ringham 2000:75). It is the veridiction status of what is not but appears as - real. If something seems to be real but is not, there is a lie or illusion. This corresponds to falsification that engenders deception.

These four modal categories of the semiotic square of veridiction will now be applied to the story of Susanna. This article contends that veridiction is particularly important in Susanna. In fact, as the story unfolds, the veridictory modalities être and paraitre [being and appearing] constitute the most influential modes of persuasion. In other words, the main actors appear in the story in terms of being and seeming. For the purpose of this study only Susanna, the elders, God and Daniel are investigated. Moreover, the construction of important spaces such as the garden is also analysed.

\section{Games of truth in Susanna}

The expression 'games of truth' was first used by Michel Foucault in relation to the production of discourses. Foucault argued that in these games, discourses interact 'as weapons of attack and defence in the relations of power and knowledge'(Smart 2002:77). The game does not aim at producing 'objectively true' discourses, but efficiently persuasive discourses (Kanonge 2010:172). The construction of persuasive discourses may even comprise illusion based on twisting the truth, as will be revealed shortly. The creation of illusions serves to produce some effects of truth (Greimas \& Courtés 1979:418) aimed at persuading people to act accordingly. One way of convincing people is the construction of bodies and space, which this article focuses on as the main mode of veridiction in the story of Susanna. In the Greimassian approach, the construction of bodies, which consists in establishing actors in a story, is called 'actorialisation'. On the other hand, the construction of space in a narrative is called 'spatialisation'. The following section is devoted to actorialisation, establishing the actors' bodies.

\section{Actorialisation}

Susanna comprises many actors, but for the sake of this study, only main ones such as Susanna, the elders, God and Daniel are taken into account. The construction of bodies in a text cannot be underestimated. In fact, according to Brooks (1993:25), 'the body is a key sign in narrative and a central nexus of narrative meanings'. Indeed, getting the body into writing is a primary concern of literature (Brooks 1993:1).

Constructing an actor's body entails giving particular pieces of information, providing discourses that define the man or 
the woman and their bodies (George 1999:395). Michel Foucault (quoted by George 1999:6) suggests that bodies become meaningful when they are inscribed and invested with discourses constructed by the societies within which they live and develop. These discourses - such as a person's gender, physical size, family, place of origin, religious affiliation, occupation, ethnic origin, appearance (beautiful or ugly) and so on - are the systems of knowledge employed within societies in order to know, define, particularise and thus control bodies.

The first body discussed will be Susanna.

\section{Susanna}

Susanna is the most referred to in the narrative: we find 49 mentions (vv. 2, 3, 7, 8, 10, 11, 12, 14, 15, 16, 17, 18, 19, 20, 21, $22,23,24,26,27,28,29,30,31,32,33,34,35,36,37,38,39,40$, $41,42,43,44,45,46,48,49,5457,58,60,61,62,63)$. There is much to say about her body; for the sake of this article, however, only a few pieces of information are included. Her body is constructed and distinguished from that of the elders; her identity is revealed through her gender, her name, her husband's wealth, her beauty and particularly her relationship with God in terms of trust, prayer and observance of the law.

The first core aspect of Susanna is her anthroponym (proper

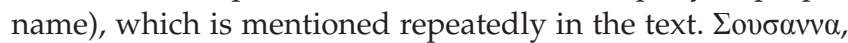
as a personal name, however, does not appear elsewhere in the LXX. It comes from the transliteration of the Hebrew שוֹשָשָנָה (Moore 1977:95; cf. Fisch 1996:37), meaning 'lily' or 'lotus flower'. In 1 Kings 7:19, 22, 26 and 2 Chronicles 4:5 this term refers to the decoration of two pillars (Jakin and Boaz) in Solomon's temple (Carson et al. 1994). Similarly, the rim of the big bronze basin called 'the Sea' was shaped like a lily blossom. In these two passages, the lily probably symbolises beauty and purity (Goodspeed 1971:70).

In Song of Songs $(2: 1-2,16 ; 4: 5,13 ; 6: 2-3 ; 7: 2)$ the lily represents beauty and love (Exum 2005:112). Finally, in Hosea

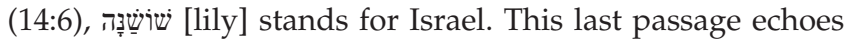
Psalm 1, where the just one is compared to a tree planted by the streams of water. The lily, here, is likely the symbol of righteousness (Farbridge 2003:46).

The name Susanna is thus symbolically rich. It stands for beauty, purity, righteousness, and is a metaphor for Israel. שוֹשָ matches the main characteristics ascribed to Susanna in the story, as evidenced below.

Her association with Joakim, a wealthy man, calls to mind other stories such as Joseph and Esther, where a member of a Jewish community rises for the benefit of the entire people. Likewise, Susanna embodies God's intervention at a critical time for the Jewish people. Her heroic achievement consists of preserving the Law of Moses, the unique symbol of Jewishness. In this story, the Jewish identity seems to be endangered by the Jews' own attempts to conform to the Babylonian way of life (Nickelsburg 2005:24).

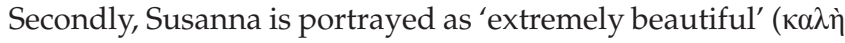
$\sigma \varphi o ́ \delta \rho \alpha$ ) and 'fearing the Lord' ( qualities central to the construction of her identity in the narrative (Bohn 2001:259). In fact, beauty not only leads Susanna's commitment to the law to be tested but also functions as bait to entice corrupt Jewish leaders and preserve her community from wickedness.

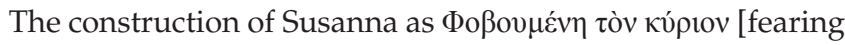
the Lord] is also very significant here: the feminine form

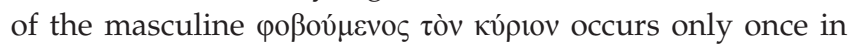
the entire LXX. This quality relates to the law, the token of Jewishness, and as such, Susanna's body represents the embodiment of Jewishness. In other words, her identity and the way it is constructed tells the Jewish community something about their own identity, that is, that Jewish identity must be defined by commitment to the law.

Susanna's 'lifting of eyes to heaven' is also another important trait of her identity revealing her trust in God. In fact, she does not claim her innocence until the death sentence is announced and Daniel's involvement has resulted from Susanna's prayer (44). Therefore, she becomes an embodiment of the Lord's presence in her community, an extension of God's space.

In a nutshell, the construction of Susanna here tells the Jews that an approved body in the Jewish community must be defined in terms of intrinsic purity and righteousness stemming from fear of the Lord, commitment to the law and that it entails trusting the Lord even to the cost of one's own life.

It is important to notice that all of Susanna's qualities are defined in terms of being but not seeming.

\section{The elders}

The elders are presented from the beginning in terms of

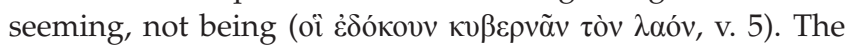
verb ठокєіv depicting their leadership generally means 'to think'; in this context however, it could mean 'to seem' or 'to appear', according to lexicographers such as Bauer and Danker (2000), Liddell et al. (1996:442) and Lust (2001). Accordingly, Moore (1977:93) translates the last part of v. 5 using 'seeming' as follows: '... elders who as judges only seemed to guide the people.'

Their lack of names, which is also one of their prominent characteristics, bears the same connotation. According to Herodotus (cited by Bientenhard 2000:243), to be without a name is abnormal. In both Biblical and Jewish traditions, lacking a name implies being without identity (cf. Cornwall \& Smith 1998:vi). Their anonymity may intend to hide their true identity, as if to them seeming is more important than being.

Now, we know that the two individuals threatening Susanna are elders. According to Delcor (quoted from Steussy 1993:109) the word 'elders', $\pi \rho \varepsilon \sigma \beta v ́ \tau \varepsilon \rho o r$ [plural], seems to be an allusion 
to the institution rather than the age of the individuals. In fact, elders constituted an important authority in Israel (Nm 11:16-17, 24-30) (Bornkamm 2000:654). In the narrative, the two elders represent the leading class. In fact, according

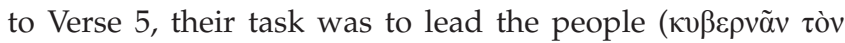
$\lambda \alpha o ́ v)$. According to George (1999:5), leaders (kings) in Israel were supposed to 'embody the identity of the nation in their person and office'. In contrast, here the elders are associated with wickedness and sexual perversion, inspired by Babylon (v. 5). As a result, their portrait here is incompatible with their function of judges and protectors of people's rights (Jordaan 2008:121). On the contrary, they are the embodiment of evil and the extension of Babylonian space. Their main aim is to have a Jewish community without the law and thus without God. This twofold project is revealed by their designation as $\pi \alpha \rho \alpha ́ v o \mu o r$ [anti-law or law-breakers (Dancy 1972:233)] (v. 32), as well as by their metaphorical gesture of 'turning their eyes against heaven' (v. 9). According to Dancy (1972:227), their injustice is seen as a form of practical atheism: 'It involves the rejection of God's will'. Susanna thus does more here than saving the Jewish community; she actually saves the presence of God.

As judges, the elders could manipulate the judicial system, protect themselves and condemn or clear whomever they wished. As a dual actant, their joint witness, be it true or false, would be difficult to unmask. In fact, according to the regulation of the law, at least two witnesses, not one, were enough to condemn someone to death ( $\mathrm{Nm}$ 35:30; Deuteronomy 17:6, 7 and 19:15), the aim of which was not only plurality of testimonies but also independence, which is not achieved here. Indeed, though the elders are two individuals, they are not independent from each other.

Further, their portrayal as 'seed of Canaan' ( $\Sigma \pi \dot{\varepsilon} \rho \mu \alpha$ X $\alpha v \alpha \alpha v)$ seems to emphasise their corruption. In biblical tradition, Xava $\alpha v$ echoes the voyeurism of Cham and the ensuing curse. Here, the two elders seem to symbolise a body forbidden within the Jewish community.

In summary, the construction of the elders' body focuses on their appearance as main weapon of manipulating people about the truth. It is not only impossible for Susanna to overcome their opposition, but also for the Jewish community to unmask their lawlessness. Implicitly, the story indicates that their action was beyond human understanding or crossexamination. Only a supernatural detective such as God who is omniscient could be up to the task.

\section{God}

God's first intervention here seeks to warn the Jewish community against wickedness (v. 5). He is called ó $\theta \varepsilon$ ò , $_{\text {, }}$

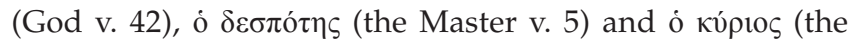
Lord v. 24). All these names reveal his special involvement in the community and his supernatural nature. Nonetheless, apart from Verse 5, God does not appear directly in the story. Consequently, some scholars, like Gruen (2002), conclude that:
God's involvement is distant and oblique, alluded to, rather than directly felt. He stirred up Daniel's spirit, but the spirit, it seems, was already there. Certainly, the Lord plays no role through most of the text. Daniel performed his own task with personal energy and efficiency. (p. 172)

The assumed absence of the Lord, however, is only a deliberate communication strategy adopted throughout the story. In fact, God acts in accordance with his status as a subject manipulator (Kanonge 2010:142). 'Manipulation' denotes a remote action but not disinterestedness. In general, 'manipulation' has a negative connotation; here, however, it is a technical term used in semiotic analysis.

'Manipulation' denotes the action of the addresser on the addressee to make him act (faire). It is synonymous with the word 'causation'. Linguistically, the semantics of 'causation' include direct and mediated causation, manipulation and direction, and coercion and permission (Kroeger 2004:204208). In the Greimassian approach, causation is represented by the French modal expression faire faire [cause to do], which opens four different modes of manipulation, as follows: 'intervention (faire faire, cause to act), 'obstruction' (faire ne pas faire, cause not to act), 'non-intervention' (ne pas faire faire, not cause to do) and 'laisser faire' (ne pas faire ne pas faire, not cause not to do; non-obstruction). These characterise the action of the addresser (Greimas \& Courtés 1979:220). Evidence from Susanna suggests that God's action here does indeed conform to these four modes of manipulation (Kanonge 2010:143).

In brief, a superficial reading of Susanna may conclude that God does not appear actively in it. Contrarily, a semiotic investigation sees his intelligence everywhere in the story. In fact, his causative action controls events and circumstances. His direct intervention (faire faire) as well as his nonintervention (ne pas faire faire), his obstruction (faire ne pas faire) as well as his laissez-faire (ne pas faire ne pas faire, not causing not to do) all serve his design.

For example, it emerges from Susanna's prayer that nothing is hidden to God (v. 42) and thus God controls everything in the narrative, from start to finish. Accordingly, he acts as the true detective, using Daniel.

\section{Daniel}

Daniel is the last major actor to appear in the story. His name means 'God has judged' (Moore 1977:108). His introduction in the narrative emerges as a special act of God's intervention on behalf of Susanna. The narrative declares that 'God aroused the holy spirit of a mere child named Daniel'. The

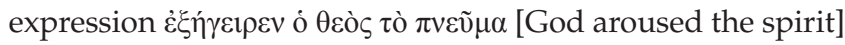
appears in other books such as 2 Chronicles 36:22; Ezra 1:1, 5 and Haggai 1:14. In each of the mentioned passages, God raises a person to act as his instrument and achieve his will. In Susanna, the verb $\dot{\varepsilon} \xi \varepsilon \gamma \varepsilon i p \varepsilon v$ serves to highlight the instrumentality of Daniel and to accredit God as the subject of the action: he is the one who causes. 
Daniel assumes an important function in the story, but some scholars exaggerate his role and make him the central figure. McDowell (2006:72), for example, claims that the primary purpose of Susanna seems to be a story about the wisdom of Daniel'. In the same way, Schiffman (1998:323) argues that 'the tale is intended to show the wisdom of Daniel even as a youth'. This view is shared by various other scholars, mainly feminists, as Tkacz (2008:181-196) reveals.

Moore holds an alternative view. Daniel, Moore (1977:90-91) contends, 'is not the hero here, but Susanna is'. Moore's view seems to be supported by data from the text. Firstly, Daniel's intervention is clearly presented by the narrator as an answer

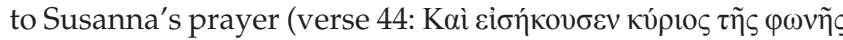
$\alpha$ ${ }^{\tau} \tau \tilde{\eta}$, 'and the Lord heard her voice').

Secondly, the verb $\grave{\varepsilon} \xi \varepsilon \gamma \varepsilon i ́ p \omega[$ [ raise up], as said above, reveals that Daniel is used passively as an instrument. Although the verb is in active form, it is not a simple active form but rather a causative active that can be translated 'I cause to raise up' (Dana \& Mantey 1927:156; Robertson 2006:801). A better

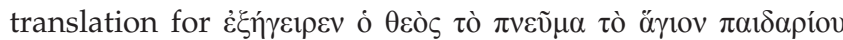

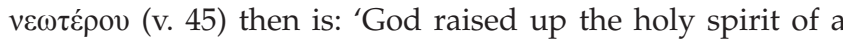
young youth' (Charles 1913; BDAG 2000:346). Surely, God is the cause of Daniel's intervention.

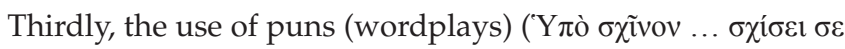

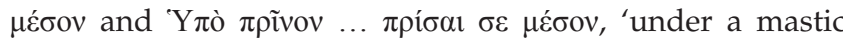
tree ... he [the angel] shall cut you in the middle' and 'under a holm tree ... he shall cut you in the middle') suggests that Daniel acts under inspiration. Doran (2008:245-247) formulates this as follows: 'Wordplays are generally part of dream and omen interpretation. The wordplay Daniel uses reveals his position as an interpreter'.

Puns also play an important role in the book of Daniel (Arnold 1993:479-485) and in the story of Joseph (Wilson 2004:118). In these books, however, it is not the ability of the interpreter that is important but the action of God. About Daniel and Joseph's narratives, Fox (2001) contends that:

The book of Daniel shares and elaborates the Joseph story's idea that the wisdom of dream interpretation is a divinely communicated message, rather than a talent or a learned skill. Joseph's story and, more deliberately, the book of Daniel, create a rank of dream interpretation beyond the ordinary. Decoding by inspiration trumps decoding by expertise, yet keeps the status of wisdom (hokmäh, bînah). Oneiromancy is displaced by prophecy. (p. 40)

In Susanna, puns have the same function as in Joseph and Daniel's stories: they reveal that Daniel judges by inspiration. Like Daniel and Joseph's capacity to interpret dreams, Daniel's judgment depends on God, not on his natural human abilities.

Fourthly, Daniel's affirmations in the story presuppose direct revelations rather than common knowledge. His discovery of

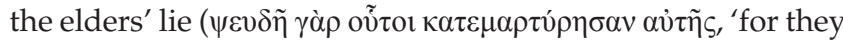
have testified lie against her'), his knowledge of their wicked judgments and arbitrary 'condemning of the innocents'

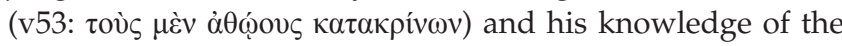
elders' forced sexual intercourse with Jewish women (oũ $\tau \omega \varsigma$

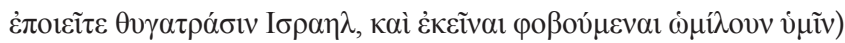
are found nowhere in the story.

Fifthly, Daniel is introduced in the story as $\pi \alpha 1 \delta \alpha \rho i ́ o v ~ v \varepsilon \omega \tau \varepsilon$ pov (a mere young boy) (v. 45). The word $\pi \alpha 1 \delta \alpha$ piov with the

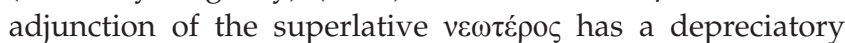
connotation (Dunn 1982:25). It depicts Daniel as a 'mere mere child' (Liddell et al. 1996:1286) with no expertise in judicial

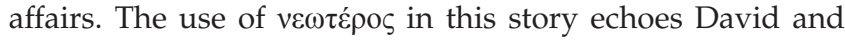
Goliath (1 Samuel 17) where Saul doubts David's ability to confront Goliath (1 Samuel 17:32-33) as David is but a mere child.

One may notice, from the double negation (v33, ov̉ $\mu$ ì, 'by no means'), that Saul finds it impossible for David to stand

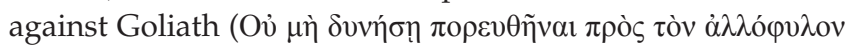

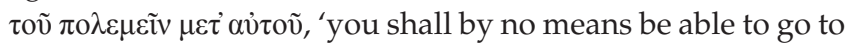
the Philistine to fight against him'). The impossibility of the confrontation stems from David's immaturity (ö $\tau \iota \pi \alpha \iota \delta$ ópıv cĩ $\sigma v ́$, 'because you are a child') and his lack of military experience compared to Goliath's reputation as a professional

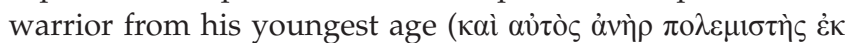

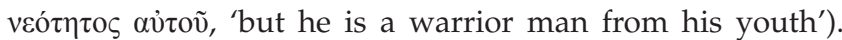
$\Pi \alpha 1 \delta$ ópıv doubled with $v \varepsilon \omega \tau \varepsilon \dot{\rho} \rho \varsigma$ here indicates that Daniel is depicted as even younger than David and thus less experienced to judge than he was.

Sixthly, Susanna deals with persecution and vindication of the righteous (Nickelsburg 2006:66, 74). Now, these kinds of stories abound in biblical tradition and have their own structure. Indeed, according to Nickelsburg (2006:66, 74), the structure comprises, inter alia, reasons (for persecution), conspiracy, choice, accusation, trial, condemnation, protest, intervention of a helper, rescue, acclamation, exaltation, vindication and punishment. Daniel is not the 'suffering righteous one' here; he may fit into the narrative as a helper, as suggested by Nickelsburg $(2006: 66,74)$. It is thus debatable whether Daniel could be the hero of the story, as Cornelius (2008:100) assumes, based only on his intervention to rescue Susanna.

Moreover, this logic falls short when comparing Susanna to other events in the book of Daniel. Habakkuk, for example, should then also be considered the hero in the episode of Daniel and the dragon (cf. Craven 1998:313), and the angel should be the hero for saving Shadrach, Meshach and Abednego from the burning fiery furnace (Daniel 3). Likewise, the hero when Daniel was in the lions' den (Daniel 6) would be the angel, and not Daniel. All these events, as DiTommaso (2005:61) demonstrates, have structures similar to Susanna and should be approached in the same way.

Halpern-Amaru (1996) is of the opinion that Daniel's role in the story is not central:

In spite of the celebration of youth at the end of the story, the reader is quite aware that it is divine intervention, not Daniel's wisdom that brings the narrative to resolution. (p. 22) 
Arguing from the similarity of Susanna with passages in Daniel, Mendels (1992:426) concludes that: 'in the book of Susanna, Daniel plays a secondary role (the real hero is Susanna), whereas in Daniel 1-6 he is the main character'.

In brief, the games of truth here are played by Susanna and the elders as two opposing parties, and God as detective. Consequently, Susanna reads as a construction of bodies: the virtuous body (exemplified by Susanna), allowed in the Jewish community, and the wicked body (embodied by the elders), prohibited within the community of God's people.

The following section investigates the role of space in terms of spatialisation.

\section{Spatialisation}

The book of Susanna is set in Babylon. Noticeable places where actions take place are Joakim's house and Joakim's garden, while Babylon and heaven also play determinant roles. They are associated with the main actors, namely Susanna and the elders.

\section{Babylon}

The word 'Babylon', in this context, not only represents a setting but also carries an ideological connotation. In fact, as Ryken (1998:68) assumes: 'Babylon is one of the dreaded images of the Bible'. It is the power that inspires wickedness. According to Kittel $(2000,1: 514)$, ‘[ $t]$ he historic city and empire of Babylon were always depicted by the prophets as the ungodly power par excellence'. Babylon in the Bible represents more than a historical reality. After Nebuchadnezzar destroyed Jerusalem and exiled many of its inhabitants (see pp. 110-113), it was viewed as the embodiment of all evil, a kingdom of wickedness set against God and his chosen people, a powerful and complex symbol of pride, oppression, wealth, luxury, sexual debauchery and idolatry (Porter 1998:35). Babylon is the space associated with the elders.

\section{Heaven}

Heaven also plays an important role as a direct opposite to Babylon and inspiring an ideology opposed to Babylon's. While heaven is a place to avoid for the elders, for Susanna, it is where help comes from. In fact, the story stipulates that, for the elders:

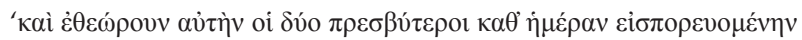

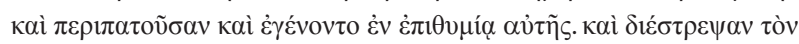

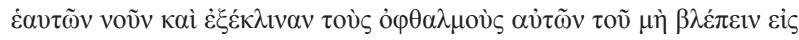

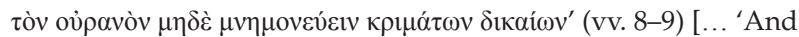 the two elders beheld her going in every day, and walking; and they were inflamed with love for her. And they perverted their own mind, and turned away their eyes, that they might not look unto heaven, nor remember just judgements']. (Ralf 1996, [author's own translation])

Contrarily, about Susanna the story declares (v. 35): ' $\dot{\eta} \delta \dot{\varepsilon}$

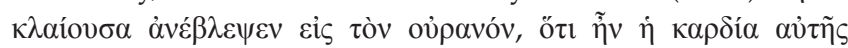

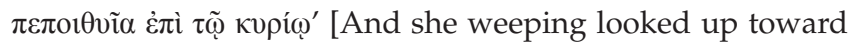
heaven: for her heart trusted in the Lord].

\section{Joakim's house and garden}

Joakim's house is where the action starts, but nothing actually happens inside; it all occurs in the garden. It is also where Susanna confronts the elders. In semiotic tradition, this is generally called the 'topic space' and is considered an unusual location (Greimas \& Courtés 1979:214-216).

In Susanna, the garden is called expressively $\pi \alpha \rho \alpha ́ \delta \varepsilon 1 \sigma o \varsigma$ [paradise]. This term acquired a negative connotation when associated with women. In Jewish tradition, $\pi \alpha \rho \alpha$ ó $\varepsilon 1 \sigma o \varsigma$ invokes Eden, which is a synonym for sin, and sin comes from Eve. In the Wisdom of Ben Sira, for example, Eden is evoked indirectly, in relation with women, as source of sin. In

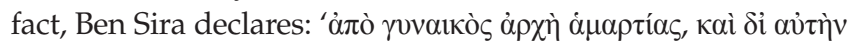

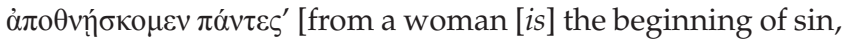
and because of her, we all die]. From this passage, 'woman' designates Eve, who represents all women (cf. 1 Tm 2:14).

Eve's association with sin in Eden resulted in her becoming the prototype of all women. Nelson (2006; cf. Aschkenasy 1986:40) argues that:

[T] he three traits of the biblical Eve that were assumed to prefigure the essence of womanhood are productivity for evil, destructive sexuality, and a demonic-deadly power. There is no direct reference to sexuality in the account of Eden. Sexuality, however, is suggested in their attempt (Adam and Eve) to cancel out their nakedness by making loincloths, that is, something to cover their genitals. (p. 35)

Joakim's garden is an ambiguous space, both private and public, allowed and forbidden to women. Susanna can go into the garden only at noon: it is a liminal space. A liminal space allows crossing social boundaries (Turner 1979:465). In Susanna, separation between men and women is a fixed boundary likely aimed at avoiding sexual pollution. On the other hand, it helps to maintain men's assumed spiritual and moral superiority over women. The garden, because of its public-private ambiguity, can be an appropriate place where women and men meet by chance. The author uses Joakim's garden metaphorically as a battlefield where ingrained prejudice against women is deemed to be reversed.

In Susanna, the settings are clearly not coincidental and contribute to the meaning of the story: heaven and Babylon represent two symbolic spaces against which actors are portrayed and that influence their actions. Heaven (God) stands behind Susanna's struggle to uphold the law, while Babylon inspires lawlessness to the elders. It is only if and because Susanna turns to heaven that she can change her destiny and that of her community.

As mentioned above, Joakim's house and garden are two important locations in the narrative. The first is where Susanna starts her course but she does not remain inside her house. The latter, despite its negative connotation, is closely connected to her and her course. The association of Susanna with the garden ( $\pi \alpha \rho \alpha ́ \delta \varepsilon 1 \sigma o \varsigma$, 'paradise') creates an illusion of reality about women and their assumed sexual corruption according to the 
aforementioned Jewish traditions. It is her presence in the garden, with its connotation, that creates lie and mystery.

\section{Veridiction in Susanna}

Based on être and paraître [being and seeming], the games of truth in Susanna appear on the veridictory square as shown in Figure 2.

The diagram in Figure 2 illustrates the games of truth in Susanna. Based on veridictory modalities of etre [being] and paraitre [seeming], the games of truth in the story comprise two rounds, A (vv. 2-44) and B (vv. 45-63).

\section{Lie and mystery (secrecy)}

The first round (2-44) deals with lie and mystery in the story. It illustrates the construction of reality about Susanna and the elders that rests merely on appearances, lie or illusion (paraitre and non-être) on the elders' side, and secret or mystery (être and non-paraître) on Susanna's. Falsification and mystification of truth are observed.

The verdict of truth here rests entirely on the paraitre [seeming]. Consequently, the elders' 'make-believe' acts powerfully to deceive all the community; indeed, despite her chastity, they portray Susanna as a wicked woman. The elders' wickedness is also concealed by their long robes, symbolising their office as judges and respectable leaders. Secret/mystery and lie/illusion will later on influence the other Jews and their perception of truth.

\section{Truth and falsehood}

The second part of the games of truth (45-63) reveals truth on one side and falsehood on the other. Reality here is based on

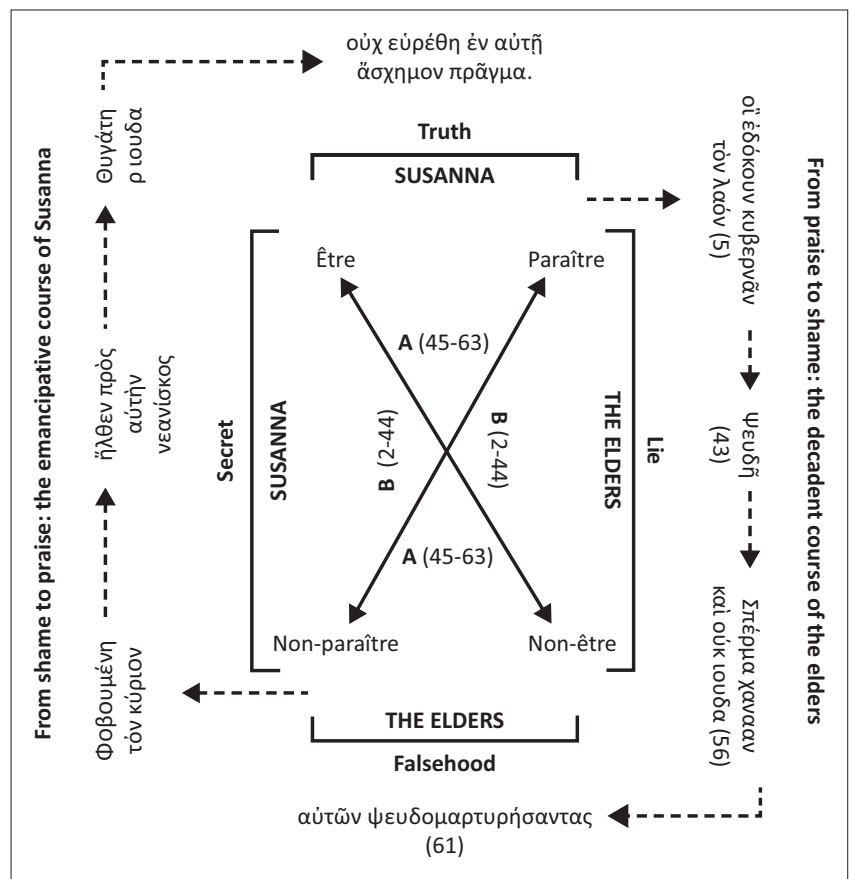

FIGURE 2: The Veridictory square underlying the persuasive of Susanna based on being être [being] and paraître [seeming]. être [being], the true nature of Susanna. We observe that Susanna's true nature is unveiled on one side, with God's intervention: only he can distinguish truth from falsehood.

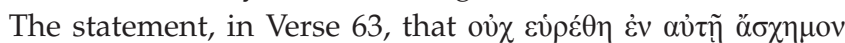
$\pi \rho \tilde{\alpha} \gamma \mu \alpha$ [there was no dishonesty found in her] pleads in favour of Susanna saying that she has nothing to hide. That means Susanna is justified; she has never been an evil one. This is the truth the story has to tell to Jews. On the other side, the elders are unmasked. In fact it is said about them in

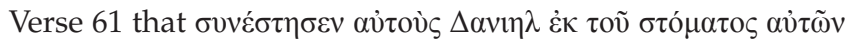

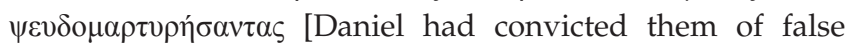
witness by their own mouth]. This statement tells all about falsehood in relation with the elders. As a result, the community learns that established conventions can be misleading, because the elders, albeit the most respectable institution, were corrupt.

\section{Conclusion}

The aim of this article was to test the effectiveness of Greimas' veridictory square in the context of the book of Susanna. This goal was achieved by retracing the games of truth in the unfolding events, in terms of truth, falsehood, secret and lie, stemming from être and paraître as discussed. Dissected with the veridictory square, Susanna reads as a detective discourse involving mysterious truth and clothed falsehood, with bodies and space constructed accordingly. To unmask falsehood within the Jewish community and reveal the truth, God acts as a detective through Daniel and uses the virtuous Susanna to trap the wicked.

This article commends Greimas' veridictory square for its effectiveness in conceptualising games of truth in narrative texts.

\section{Acknowledgements Competing interests}

The author declares that he has no financial or personal relationships which may have inappropriately influenced him in writing this article.

\section{References}

Arndt, W., Danker, F.W., Bauer, W. \& Gingrich, F.W., 2000, A Greek-English lexicon of the New Testament and other early Christian literature, 3rd edn., University of Chicago Press, Chicago, IL.

Arnold, B.T., 1993, 'Wordplay and narrative technique in Daniel 5 and 6', Journal of Biblical Literature 112, 479-485. https://doi.org/10.2307/3267746

Aschkenasy, N., 1986, Eve's Journey. Female images in Hebrew literary tradition, University of Pennsylvania Press, Philadelphia, PN.

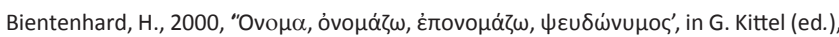
The TDNT, vol. 5, pp. 242-282, Eerdmans, Grand Rapids, MI.

Böckler, O., 1891, Apocryphen des Alten Testaments, Beck'sche Verlagsbuchhandlung, Munich.

Bohn, B., 2001, 'Rape and the gendered gaze: Susanna and the elders in early modern Bologna', Biblical Interpretation 9(3), 259-286. https://doi.org/10.1163/ 156851501317072710

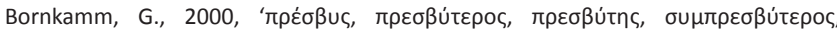
$\pi \rho \varepsilon \sigma \beta u t \varepsilon \dot{\rho}$ iov, $\pi \rho \varepsilon \sigma \beta \varepsilon \cup \dot{\omega} \omega^{\prime}$, in G. Kittel (ed.), The TDNT, vol. 6, pp.651-683, Eerdmans, Grand Rapids, MI.

Brenner, A., 1995, A feminist companion to Esther, Judith and Susanna, Sheffield Academic Press, Sheffield.

Brooks, P., 1993, Body work, Harvard University Press, Cambridge. 
Budniakiewicz, T., 1992, Fundamentals of story logic: Introduction to Greimassian Semiotics, John Benjamins Publishing Company, Amsterdam.

Carson, D.A., France, R.T., Motyer, J.A. \& Wenham, G.J. (eds.), 1994, New Bible commentary: 21st century edition, 4th edn., Inter-Varsity Press, Leicester.

Casey, P., 1976, The Susanna theme in German literature. Variations of the Biblical drama, Bouvier Verlag Herbert Grund Mann, Bonn.

Charles, R.H., 1913, Apocrypha and Pseudepigrapha of the Old Testament, vol. 1, Oxford University Press, London.

Clanton, D.W., 2006, The good, the bold, and the beautiful. The story of Susanna and its renaissance interpretations, T\&T Clark, New York/London.

Cornelius, E., 2008, 'The woman in "Susanna". An understanding of the rhetoric of "Susanna"', Acta Patristica et Byzantina 19, 97-109. https://doi.org/10.1080/102 26486.2008.11745789

Cornwall, J. \& Smith, S., 1998, The exhaustive dictionary of Bible names, Bridge-Logos, Gainsville. Logos Research Systems [CD].

Courtés, J., 1991, Analyse sémiotique du discours: de l'énoncé à l'énonciation, Hachette, Paris.

Courtés, J. 1995, Du lisible au visible, De Boeck Université, Bruxelles.

Craven, T., 1992, 'Ezekiel and Daniel', in D. Bergrant \& R.J. Karris (ed.), The collegeville commentary, pp. 533-570, John Knox Press, Westminster.

Craven, T., 1998, 'The Greek Book of Daniel', in A. Newsom \& S.H. Ring (eds.), Women's Bible Commentary expanded edition, pp. 311-314, John Knox Press, Westminster.

Craven, T., 2001, 'Women as teachers of Torah in the Apocryphal/Deuterocanonical books', in L.M. Luker (ed.), Passion, vitality, and foment, pp. 275-287, Trinity Press International, Harrisburg.

Dana, H.E. \& Mantey, J.R., 1927, A manual grammar of the Greek New Testament, The Macmillan Company, Chicago, IL.

Dancy, J.C., 1972, The Shorter Books of the Apocrypha. Tobit, Judith, Rest of Esther, Baruch, Letter of Jeremiah and Additions to Daniel and Prayer of Manasseh, Cambridge University Press, Cambridge.

DeSilva, D.A., 2002, Introducing the Apocrypha, Baker Academic, MI.

Everaert-Desmedt, N., 2007, Semiotique du Recit, De Boeck, Bruxelles.

DiTommaso, L., 2005, The Book of Daniel and the Apocryphal Daniel Literature, Brill, Leiden/Boston, MA.

Doran, R., 2008, 'The good, the bold, and the beautiful: The story of Susanna and its renaissance interpretation, by Dan W. Clanton (Review)', Review of Biblical renaissance interpreta
Literature $10,245-247$.

Dunn, R., 1982, 'Discrimination in the comic spirit in the story of Susanna', Christianity and Literature 31, 19-31.

Exum, J.C., 2005, Song of songs, John Knox Press, Westminster.

Farbridge, M.H., 2003, Studies in Biblical and Semitic symbolism, Kessinger Publishing, Whitefish.

Fisch, A., 1996, 'Susanna as a parable: A response to Piero Boitani', in E. Spolsky (ed.), The Judgment of Susanna Authority and Witness, pp. 35-41, Scholars Press, Atlanta, GA.

Fox, M., 2001, 'Wisdom in the Joseph story', Vetus Testamentum 51(1), 26-41. https:// doi.org/10.1163/156853301300102183

George, M., 1999, 'Constructing Identity in 1 Samuel 17', Biblical Interpretation 7(4), 389-412. https://doi.org/10.1163/156851599X00290

Goodspeed, E.J., 1971, The Story of the Apocrypha, University of Chicago Press, London.

Greimas, J.A. \& Courtes, J., 1979, Sémiotique, Dictionnaire Raisonné du Langage, Hachette, Paris.

Greimas, A.J. \& Rastier, F., 1968, The interaction of semiotic constraints, Yale, French Studies 41.

Gruen, E.S., 2002, Diaspora: Jews amidst Greeks and Romans, Harvard University Press, Cambridge.

Halpern-Amaru, B., 1996, 'The journey of Susanna among the Church fathers', in E. Spolsky (ed.), The Judgment of Susanna authority and witness, pp. 21-34, Society of Biblical Literature, Atlanta.

Harrington, D.J., 1999, Invitation to the apocrypha, Eerdmans Publishing Company, Grand Rapids/Cambridge.

Harries, K., 2001, Infinity and perspectives, The MIT Press, Cambridge, MA.

Hénault, A., 1983, Narratologie Sémiotique Générale. Les enjeux de la Sémiotique II, Presses universitaires de France, Paris.

Ilan, T., 2001, Integrating women into second temple history, Hendrickson Publishers, Peabody, MA.

Jordaan, P.J., 2008, 'Reading Susanna as therapeutic narrative', Journal for Semitics 17 114-128.

Jordaan, P.J. \& Kanonge, D.M., 2006, Women (whores), wars and wisdom, Ekklesiastikos Pharos.

Kanonge, D.M., 2010, 'The emergence of women in the LXX Apocrypha: A Semiotic Study of Susanna', Unpublished PhD thesis, Department of Greek, North West University, Potchefstroom.

Kautzsch, D.E., 2009, Apocryphen und Pseudepigraphen des Alten Testaments, BiblioBazaar, Charleston, SC.

Kay, D.M., 1913, 'Susanna', in R.C. Charles (ed.), The Apocrypha and Pseudepigrapha of the Old Testament, pp. 638-651, Clarendon Press, Oxford.
Kittel. G., 2000, 'B $\alpha \beta \nu \lambda \omega v^{\prime}$, in G. Kittel (ed.), The TDNT, vol. 1, pp.514-546, Eerdmans, Grand Rapids, MI.

Kottsieper, I., 1998, Das Buch Baruch Der Brief des Jeremia Zu Esther und Daniel, Vandenhoeck \& Ruprecht, Göttingen.

Kroeger, P.R., 2004, Analyzing syntax. A lexical-functional approach, Cambridge University Press, Cambridge.

Liddell, H. G., Scott, R., Jones, H. S. \& McKenzie, R., 1996, A Greek-English lexicon, Clarendon Press, Oxford.

Longman, T., 1996, 'Literary approaches to biblical interpretation', in M. Silva (ed.), Foundations of contemporary interpretation, pp. 95-192, Zondervan, Grand Rapids, MI.

Martin, B. \& Ringham, F., 2000, Dictionary of Semiotics, Cassel, London/New York.

Martin, B., 2006, Key Terms in Semiotics, Continuum, New York.

McDowell, 2006, Prayers of Jewish Women: Studies of Patterns of Prayer in the Second Temple Period, Mohr Siebeck, Tühingen.

Mendels, D.M., 1992, 'Susanna', in G.A.H. Freedman (ed.), The Anchor Bible Dictionary, vol. 6, pp. 246-246, Doubleday, New York.

Metzger, B.M., 1957, An introduction to the apocrypha, Oxford University Press, New York.

Mills, W.E. \& Wilson, R.F., 2002, Deuterocanonicals/Apocrypha, The Mercer University Press, Mercer.

Moore, C.A., 1977, Daniel, Esther and Jeremiah: The Additions, Doubleday \& Company, Garden City.

Nelson, R.D., 2006, From Eden to Babel: An adventure in Bible study, Chalice Press, Atlanta, GA.

Nickelsburg, G.W.E., 2005, Jewish Literature between the Bible and the Mishnah. A historical and literary introduction, Fortress Press, Minneapolis, MN.

Nickelsburg, G.W.E., 2006, Resurrection, immortality, and eternal life in intertestamental Judaism and early Christianity, expanded edn., Harvard University Press, Cambridge, MA

Oesterley, W.O.E., 1935, An introduction to the books of the Apocrypha, The Macmillan Company, New York.

Pfeiffer, 1949, History of New Testament Times, with an Introduction to the Apocrypha, Harper \& Brothers, New York.

Pottier, R., 2006, 'Carré Sémiotique et Interprétation des Récits Mythiques', Sign Systems Studies 34(2), 403-415.

Porter, E., 1998, Dictionary of Biblical criticism and interpretation, Routledge, London.

Rahlfs, A., 1996, Septuaginta: Morphologically tagged edition, Deutsche Bibelgesellschaft, Stuttgart.

Ricoeur, P., 1989a, 'Greimas's narrative grammar', New Literary History 20(3), 581-608, Spring. https://doi.org/10.2307/469355

Ricoeur, P., 1989b, 'Figuration et configuration. A propos du Maupassant de Greimas', in H. Parret \& H.-G. Ruprecht (eds.), Exigences de la Sémiotique. Recueil d'hommages pour Algirdas Julien Greimas, pp. 801-809, John Benjamins, Amsterdam.

Robertson, A.T., 2006, Grammar of the Greek New Testament in the light of historical research, 3rd edn., (digitized by Ted Hildebrandt at Gordon College, Wenham, MA), Hodder \& Stoughton, London.

Ryken, L., 1998, Dictionary of Biblical imagery, InterVarsity Press, Downers Grove, IL.

Schiffman, L.H., 1998, Texts and traditions: A source reader for the study of second temple and Rabbinic Judaism, KTAV Publishing House, Hoboken, NJ.

Schleir, R., 1987, A.J. Greimas and nature of meaning: Linguistics, semiotics and discourse theory, University of Nebraska Press, Lincoln, NE.

Smart, B., 2002, Michel Foucault: Revised edition, Routledge, New York.

Speelman, M.W., 1995, The generation of meaning in liturgical songs, Kok Pharos Publishing House, Kampen.

Steyn, G.J., 2008, 'Beautiful but tough. A comparison of LXX Esther, Judith and Susanna', Journal for Semitics 17(1), 156-181.

Steussy, M.J., 1993, Gardens in Babylon. Narratives and faith in the Greek Legends of Daniel, Scholar Press, Atlanta, GA.

Sundberg, A.C., 1996, 'Protestant Old Testament canon: Should it be re-examined?', CBQ 2(28), 194-203.

Tkacz, C.B., 1998, 'Silencing Susanna: Neosexism and the denigration of women', The Intercollegiate Review 31-37, Fall.

Tkacz, C.B., 2008, 'Susanna and the pre-Christian book of Daniel: Structure and meaning', Heythrop Journal 49(2), 181-196. https://doi.org/10.1111/j.1468-2265. 2007.00367.x

Tate, M.E., 1968, 'Old Testament Apocrypha and the Old Testament canon', Review \& Expositor 3(65), 339-356. https://doi.org/10.1177/003463736806500309

Turner, V., 1979, 'Frame, flow and reflection: Ritual and drama as public liminality', Japanese Journal of Religious Studies 6(4), 465-499. https://doi.org/10.18874/ jjrs.6.4.1979.465-499

Wills, L., 2004, Ancient Jewish Novels an Anthology, Oxford University Press, Oxford.

Wilson, L., 2004, Joseph wise and otherwise. The intersection of wisdom and covenant in Genesis 37-50, Paternoster, Carliste.

Ziegler, J., 1999, Susanna Daniel Bel et Draco, Vandenhoeck \& Ruprecht, Gottingen. 